\title{
PENGARUH PENERAPAN INSTRUMEN PPI SNARS TERHADAP KESEJAHTERAAN PSIKOLOGIS PETUGAS PENANGGULANGAN COVID-19
}

\author{
Sukma Yunita ${ }^{1}$ \\ Universitas Haji Sumatera Utara, Medan, Indonesia \\ Sukmayunita28@gmail.com
}

\begin{abstract}
Abstrak
Coronavirus disease-19 (COVID-19) pertama kali ditemukan di Wuhan, Provinsi Hubei, China pada akhir tahun 2019, Perawat merupakan garda terdepan (frontline) dalam menangani masalah kesehatan salah satunya COVID-19. SNARS meliputi prinsip-prinsip standar peraturan perundang- undangan termasuk pedoman dan panduan di tingkat Nasional baik dari pemerintah maupun profesi yang wajib dipatuhi dan dilaksanakan oleh rumah sakit di Indonesia, tujuan penelitian ini untuk mengetahui Pengaruh Penerapan Instrumen PPI SNARS (Standar Nasional Akreditasi Rumah Sakit) Terhadap Kesejahteraan Psikologis Petugas Penanggulangan Covid-19 Di RS Umum Gl. Tobing Tahun 2021. Penelitian ini menggunakan jenis penelitian kuantitatif, dengan desain crosssectional, Desain penelitian ini menggunakan desain crosssectional, Populasi dalam penelitian ini adalah seluruh perawata yang berada di RS Umum Gl. Tobing pada April 2020, sampel dengan Teknik Purposive Sampling Jadi jumlah sampel dalam penelitian ini adalah sebanyak 20 perawat covid-19, dengan teknik penelitian menggunakan uji Chi Kuadrat. Hasil penelitian ini ada pengaruh Penerapan Instrumen PPI SNARS (Standar Nasional Akreditasi Rumah Sakit) Terhadap Kesejahteraan Psikologis Petugas Penanggulangan Covid-19 Di RS Umum Gl. Tobing Tahun 2021. Saran bagi pihak manajemen agar menerapkan berbagai langkah yang telah tercantum dalam Pencegahan dan Pengendalian Infeksi (PPI) yang sudah dikenal oleh kalangan perumahsakitan dan pada saat ini diuji pengimplementasiannya. Guna meningkatkan kesiapan RS dalam mengendalikan COVID-19, PERSI bekerja sama dengan Organisasi Kesehatan Dunia (WHO) melaksanakan webinar yang diikuti seluruh direktur atau kepala RS seluruh Indonesia
\end{abstract}

Kata Kunci : Penerapan PPI SNARS; Kesejahteraan Psikologis.

\begin{abstract}
Coronavirus disease-19 (COVID-19) was first discovered in Wuhan, Hubei Province, China at the end of 2019, Nurses are one of the frontline health workers in fighting against COVID-19. SNARS includes standard principles of legislation including guidelines and guidelines at the national level both from the government and the profession that must be obeyed and implemented by hospitals in Indonesia, the purpose of this study is to determine the Effect of the Implementation of the PPI SNARS Instrument (National Hospital Accreditation Standards). Against the Psychological Welfare of Covid-19 Control Officers at Gl. Tobing in 2021. This study used a quantitative research type, with a cross-sectional design. This research design used a cross-sectional design. The population in this study were all nurses who were in Gl. Tobing in December 2020, the sample was with purposive sampling technique. So the number of samples in this
\end{abstract}


study were 20 covid-19 nurses, with the research technique using the Chi Square test.

The results of this study have a significant effect between the Implementation of the PPI SNARS (National Standard Hospital Accreditation) Instrument on the Psychological Welfare of Covid-19 Control Officers at Gl. Tobing in 2021. Suggestions for hospitals need to implement various steps listed in Infection Prevention and Control (PPI) which have been known to hospital circles and are currently being tested for their implementation. In order to improve hospital readiness in controlling COVID-19, PERSI in collaboration with the World Health Organization (WHO) conducted a webinar which was attended by all hospital directors or heads throughout Indonesia.

Keywords : Implementation of PPI SNARS; Psychological Welfare

\section{Pendahuluan}

Coronavirus disease-19 (COVID-19) pertama kali ditemukan di Wuhan, Provinsi Hubei, China pada akhir tahun 2019. Penyakit ini mudah menular sehingga menjadi perhatian masyarakat internasional. Pada Maret 2020 badan kesehatan dunia (WHO) menyatakan status pandemi terhadap COVID-19. Coronavirus disease-19 bisa mengakibatkan gangguan pernapasan, pencernaan, musculoskeletal, \& neurologi. Akan tetapi, dalam beberapa pasien tidak mengakibatkan tanda-tanda atau asimptomatik sebagai akibatnya menaikkan risiko penularan dalam kelompok rentan misalnya bayi dan lanjut usia. Saat ini belum ditemukan juga obat vaksin yang khusus buat penyakit COVID-19 (Yuen KS,dkk, 2020). Data WHO pada 8 Juni 2020 menyebutkan total pasien secara global yang didiagnosa positif COVID-19 berjumlah 6.931 .000 orang dan 400.857 orang diantaranya meninggal dunia. Pada waktu yang bersamaan 32.033 pasien positif COVID19 dan 1.883 orang meninggal dunia dilaporkan di Indonesia. Upaya yang dapat dilakukan untuk menurunkan angka kematian dan kesakitan terkait COVID-19 yakni upaya preventif dan kuratif. Upaya preventif bertujuan menjaga orang yang masih sehat agar tidak terinfeksi, sedangkan upaya kuratif yaitu perawatan yang diberikan pada orang positif COVID-19 (Wu YC, dkk, 2020).

Perawat adalah Pahlawan garda terdepan (frontline) dalam melakukan perlawanan terhadap COVID-19. Beberapa instalasi ruangan melakukan pengurangan jumlah kunjungan pasien, tetapi tidak pada ruang gawat darurat dan ruang isolasi. Perawat yang bekerja pada ruangan memiliki risiko yang lebih besar berinteraksi dengan penderita yang dicurigai positif COVID-19. Hal tadi bisa berpengaruh terhadap kesehatan mental mereka. Penelitian sebelumnya yang dilakukan sebelum pandemi mengungkapkan bahwa perseteruan yg tidak jarang ada selama bekerja yakni kekerasan pada bentuk kalimat atau bahasa dan sanksi yg dilakukan dokter dan atasan atau sahabat sejawat. Selain itu, perawat juga khawatir terkait kondisi pasien yang dirawatnya. Penelitian ini bertujuan untuk melaporkan dampak psikologi pada perawat yang memberikan perawatan pasien COVID-19(Hu D, Kong Y, 2020). Memberikan asuhan keperawatan terhadap pasien COVID-19 bisa berdampak negatif pada psikologis perawat. Dampak negatif psikologis yang dialami sang perawat yakni kecemasan dan depresi. Kecemasan merupakan status emosional negatif yang dipersepsikan secara individual dan adalah satu gangguan psikologis yang tak jarang dialami sang perawat. Hasil penelitian sebelumnya menyebutkan bahwa penyebab kecemasan pada perawat yakni usia, status pernikahan, tingkat pendidikan, dan beban kerja (Hu D, Kong Y, 2020). 
Pelayanan kesehatan yang disediakan hendaknya komprehensif dan mudah diakses oleh masyarakat. Berdasarkan Peraturan Menteri Kesehatan No. 71 Tahun 2013 tentang Pelayanan Kesehatan Dalam Jaminan Kesehatan Nasional, Fasilitas Kesehatan adalah fasilitas pelayanan kesehatan yang digunakan untuk menyelenggarakan upaya pelayanan kesehatan perorangan, baik promotif, preventif, kuratif maupun rehabilitatif yang dilakukan oleh Pemerintah pusat, Daerah, dan/atau Masyarakat. Terdiri dari fasilitas kesehatan tingkat dasar (puskesmas, praktek dokter, praktek dokter gigi, klinik pratama dan RS kelas D) dan fasilitas kesehatan rujukan tingkat lanjutan (klinik utama, rumah sakit umum dan rumah sakit khusus) (Dewi Purnamasari, 2018).

Rumah sakit sebagai fasilitas pelayanan kesehatan tingkat lanjutan diharapkan dapat memberikan pelayanan kesehatan yang menyeluruh dan paripurna tanpa meninggalkan mutu layanan kesehatan yang diberikan. Upaya buat menjaga dan menaikkan mutu pelayanan kesehatan bisa ditempuh menggunakan akreditasi RS yang diadakan Komisi Akreditasi Rumah Sakit menjadi wujud standardisasi mutu pelayanan dan administrasi Rumah Sakit (Dewi Purnamasari, 2018). Akreditasi rumah sakit merupakan suatu proses yang independen dilakukan oleh pihak dalm negeri atau luar negeri, umumnya non pemerintah, melakukan evaluasi terhadap rumah sakit menurut standar prosedur akreditasi yang berlaku. Rumah sakit yang sudah terakreditasi akan menerima pengakuan menurut Pemerintah karena sudah memenuhi prosedur pelayanan dan manajemen yang ditetapkan. SNARS adalah standart pelayanan serius dalam pasien buat menaikkan mutu dan keselamatan pasien menggunakan pendekatan manajemen risiko pada Rumah Sakit yang terdiri 16 bab buat rumah sakit Pendidikan dan 15 bab buat rumah sakit nonpendidikan sebagai akibatnya pada masa pandemi covid-19 diperlukannya penerapan instrumen PPI SNARS (standar nasional akreditasi rumah sakit) terhadap kesejahteraan psikologis petugas penanggulangan COVID-19. (KARS, 2017).

Kelebihan SNARS dibandingkan Versi 2012 yaitu terdapat penambahan 2 standar baru pada bab MDGs yaitu Pengendalian Resistensi Antimikroba dan Pelayanan Geriatri, serta 1 standar baru untuk rumah sakit Pendidikan yaitu Integrasi Pendidikan Kesehatan dalam Pelayanan Rumah Sakit (IPKP). Secara berkala setiap 3 tahun standar akan di revisi, bila standar tidak lagi sesuai dengan praktik pelayanan kesehatan mutakhir, dan teknologi pada umumnya, praktik manajemen mutu, dan lainnya maka standar akan disesuaikan denga yang terbaru. Acuan yang digunakan untuk menyusun SNARS meliputi prinsipprinsip standar ISQua, standar akreditasi JCI edisi 4 dan edisi 5 versi 2012, peraturan perundang-undangan merupakan pedoman dan panduan di tingkat Nasional baik swasta, pemerintah maupun profesi wajib dipatuhi dan dilaksanakan oleh rumah sakit di Indonesia, serta hasil kajian hasil survei dari standart dan elemen yang sulit dipenuhi oleh rumah sakit di Indonesia.

RSU dr. Gl Tobing adalah Rumah Sakit Umum milik BUMN yang berada di Kabupaten Deli Serdang yang beralamat di Jl. Deli Serdang - Lubuk Pakam, Desa Buntu Bedimbar, Kec. Tanjung Morawa, Kabupaten Deli Serdang, Sumatera Utara data terdiri 4 orang, Perawat Bedah 1 Orang, Perawat Gigi 1 Orang, Perawat Lainnya 129 Orang, pada masa pandemi covid-19 ini banyak pegawai yang merawat merasa kurangnya Kesejahteraan Psikologis Petugas Penanggulangan Covid-19, dikarenakan mereka harus bekerja lebih ekstra dimasa pandemi,dan tidak adanya tunjangan kesehatan bagi perawat covid-19 itu sendiri, sehingga diperlukannya penegasan dari Standar Nasional Akreditasi Rumah Sakit dalam meningkatkan kesejahteraan bagi perawat di masa pandemi covid-19. 


\section{Metode Penelitian}

Jenis penelitian yang digunakan adalah Pre-eksperimental design yaitu rancangan penelitian yang belum dikategorikan sebagai eskperimen sungguhan. Ketiga rancangan pre-eksperimen menggunakan cara yang berbeda-beda, akan tetapi setiap rancangan diberikan perlakuan atau treatment. Penelitian ini menggunakan One Group pre-test and post-test design tanpa kelompok kontrol, kelompok subjek diobservasi sebelum dilakukan intervensi, kemudian diobservasi lagi setelah intervensi. Satu kelompok sebelum diberi treatment tertentu diberi pretest, kemudian setelah diberi perlakuan, dilakukan pengukuran lagi untuk mengetahui sebab akibat dari perlakuan. Pengujian sebab akibat dilakukan dengan cara membandingkan hasil pretest dengan posttest. Populasi penelitian ini adalah perawat yang bekerja di ruang isolasi RS Umum Gl. Tobing pada Desember 2020 berjumlah 20 orang.

\section{Hasil Penelitian Dan Pembahasan}

Setelah dilakukan penelitian pada Petugas Penanggulangan Covid-19 di RS Umum Gl. Tobing tahun 2021 diketahui data karakteristik petugas yang menjadi responden berdasarkan data demografi didapatkan dari 20 responden. Hasil data karakteristik responden disajikan dalam bentuk tabel 4.1 dibawah ini:

Tabel 4.1.

Data Karakteristik Petugas Penanggulangan Covid-19 di RS Umum Gl. Tobing Tahun 2021

\begin{tabular}{|c|c|c|c|}
\hline No & Data Demografi & Frekuensi & Presentase $(\%)$ \\
\hline \multicolumn{4}{|c|}{ Umur } \\
\hline & $20-35$ thn & 14 & 70,0 \\
\hline & $36-50$ thn & 6 & 30,0 \\
\hline & Jumlah & 10 & 100 \\
\hline \multicolumn{4}{|c|}{ Tingkat Pendidikan } \\
\hline & S1 Keperawatan & 13 & 65,0 \\
\hline & D-III Keperawatan & 7 & 35,0 \\
\hline & Jumlah & 20 & 100 \\
\hline \multicolumn{4}{|c|}{ Lama Bekerja } \\
\hline & $1-5$ tahun & 9 & 45,0 \\
\hline & 6-10 tahun & 6 & 30,0 \\
\hline & $>10$ tahun & 5 & 25,5 \\
\hline & Jumlah & 20 & 100 \\
\hline
\end{tabular}

Dari tabel 4.1 karakteristik responden berdasarkan umur mayoritas petugas yang menjadi responden berumur 20-35 tahun sebanyak 14 orang $(70,0 \%)$, mayoritas pendidikan S-1 Keperawatan sebanyak 13 orang $(65,0 \%)$, dan mayoritas lama bekerja perawat selama 6-10 tahun sebanyak 9 orang $(45,0 \%)$.

Kesejahteraan Psikologis Petugas Penanggulangan Covid-19 sebelum diberikan Penerapan Instrumen PPI SNARS (Standar Nasional Akreditasi 


\section{Rumah Sakit) di RS Umum Gl. Tobing Tahun 2021}

Data kesejahteraan psikologis petugas penanggulangan Covid-19 sebelum diberikan penerapan instrumen PPI SNARS (Standar Nasional Akreditasi Rumah Sakit) Di RS Umum Gl. Tobing Tahun 2021 dapat dilihat pada tabel 4.2 berikut :

\section{Tabel 4.2}

Kesejahteraan Psikologis Petugas Penanggulangan Covid-19 sebelum diberikan Penerapan InstrumenPPI SNARS (Standar Nasional Akreditasi Rumah Sakit) Di RS Umum Gl. Tobing Tahun 2021

\begin{tabular}{ccc}
\hline $\begin{array}{c}\text { Kesejahteraan Psikologis Petugas Penanggulangan } \\
\text { Covid-19 (Pre) }\end{array}$ & Frekuensi & Presentase (\%) \\
\hline Ringan & 2 & 10,0 \\
Sedang & 8 & 40,0 \\
Berat & 10 & 50,0 \\
\hline Jumlah & 20 & 100 \\
\hline
\end{tabular}

Berdasarkan tabel 4.2 menunjukkan bahwa Kesejahteraan Psikologis Petugas Penanggulangan Covid-19 sebelum diberikan penerapan instrumen PPI SNARS Di RS Umum Gl. Tobing Tahun 2021 mayoritas berat yaitu sebanyak 10 responden $(50,0 \%)$.

\section{Kesejahteraan Psikologis Petugas Penanggulangan Covid-19 sesudah diberikan Pengaruh Penerapan Instrumen PPI SNARS (di RS Umum GI. Tobing Tahun 2021}

Data Kesejahteraan Psikologis Petugas Penanggulangan Covid-19 sesudah diberikan Pengaruh Penerapan Instrumen PPI SNARS di RS Umum Gl. Tobing Tahun 2021 dapat dilihat pada tabel 4.3 berikut : 
Tabel 4.3

Kesejahteraan Psikologis Petugas Penanggulangan Covid-19 sesudah diberikan Penerapan Instrumen PPI SNARS Di RS Umum Gl. Tobing Tahun 2021

\begin{tabular}{ccc}
\hline $\begin{array}{c}\text { Kesejahteraan Psikologis Petugas Penanggulangan } \\
\text { Covid-19 (Post) }\end{array}$ & Frekuensi & Presentase (\%) \\
\hline Ringan & 6 & 30,0 \\
Sedang & 11 & 55,0 \\
Berat & 3 & 15,0 \\
\hline Jumlah & 20 & 100 \\
\hline
\end{tabular}

Berdasarkan tabel 4.3 menunjukkan bahwa Kesejahteraan Psikologis Petugas Penanggulangan Covid-19 sesudah diberikan penerapan instrumen PPI SNARS di RS Umum Gl. Tobing Tahun 2021 mayoritas sedang yaitu sebanyak 11 responden (55,0\%).

\section{Pengaruh Penerapan Instrumen PPI SNARS Terhadap Kesejahteraan Psikologis Petugas Penanggulangan Covid-19 Di RS Umum Gl. Tobing Tahun 2021}

Hasil uji statistik Pengaruh Penerapan Instrumen PPI SNARS Terhadap Kesejahteraan Psikologis Petugas Penanggulangan Covid-19 Di RS Umum Gl. Tobing Tahun 2021 terdapat pada tabel 4.4. sebagai berikut :

\section{Tabel 4.4.}

Pengaruh Penerapan Instrumen PPI SNARS Terhadap Kesejahteraan Psikologis Petugas Penanggulangan Covid-19 di RS Umum Gl. Tobing Tahun 2021

\begin{tabular}{|c|c|c|c|c|c|}
\hline \multirow{2}{*}{$\begin{array}{c}\text { Kesejahteraan Psikologis } \\
\text { Petugas Penanggulangan } \\
\text { Covid-19 }\end{array}$} & \multicolumn{2}{|c|}{ Pendidikan kesehatan } & \multirow{2}{*}{ Perubahan Ranking } & \multicolumn{2}{|c|}{$p$ value } \\
\hline & Sebelum & Sesudah & & $\mathrm{f}$ & $\%$ \\
\hline Ringan & 2 & 6 & Rangking Positif & 0 & \\
\hline Sedang & 8 & 11 & Rangking Negatif & 11 & $0,001 *$ \\
\hline Berat & 10 & 3 & Ties & 9 & \\
\hline
\end{tabular}

Keterangan : a) Uji Wilcoxon

Perubahan kesejahteraan psikologi:

- Ranking Negatif adalah perubahan kesejahteraan psikologi sebelum dan sesudah dari kategori 'berat' menjadi kategori 'sedang' atau 'ringan'

- Ranking Positif adalah perubahan sebelum dan sesudah dari kategori 'ringan' menjadi 'sedang' dan 'berat'

- Ties artinya tidak terjadi perubahan kesejahteraan psikologi sebelum dan sesudah 
Berdasarkan tabel 4.4 menunjukan Kesejahteraan Psikologis Petugas Penanggulangan Covid-19 di RS Umum Gl. Tobing Tahun 2021 sebelum dan sesudah diberikan pendidikan kesehatan mengalami perubahan. Kesejahteraan Psikologis Petugas Penanggulangan Covid-19 sebelum Penerapan Instrumen PPI sebanyak 10 orang petugas masuk dalam kategori berat dan sesudah penerapan instrument PPI SNARS menurun menjadi 3 orang petugas yang mengalami psikologi berat, yang ringan menjadi 6 petugas dan yang sedang menjadi 11 petugas.

Berdasarkan Hasil uji statistic dengan menggunakan Uji Wilcoxon diketahui bahwa nilai $\mathrm{p}(0,001)<\alpha(0,05)$ artinya Ho ditolak, jadi terdapat pengaruh Penerapan Instrumen PPI SNARS Terhadap Kesejahteraan Psikologis Petugas Penanggulangan Covid-19 Di RS Umum Gl. Tobing Tahun 2021. Hasil ini membuktikan bahwa Penerapan Instrumen PPI SNARS dapat memberikan pengaruh yang baik terhadap Kesejahteraan Psikologis Petugas Penanggulangan Covid-19 Di RS Umum Gl. Tobing Tahun 2021.

\section{Pembahasan}

\subsubsection{Kesejahteraan Psikologis Petugas Penanggulangan Covid-19 sebelum diberikan Pengaruh Penerapan Instrumen PPI SNARS di RS Umum Gl. Tobing Tahun 2021}

Berdasarkan hasil penelitian menunjukkan bahwa Kesejahteraan Psikologis Petugas Penanggulangan Covid-19 sebelum diberikan penerapan instrumen PPI SNARS di RS Umum Gl. Tobing Tahun 2021 mayoritas berat yaitu sebanyak 10 responden (50,0\%).

Perawat merupakan pahlawan kesehatan garda terdepan (frontline) dalam melakukan perlawanan terhadap COVID-19. Beberapa rumah sakit melakukan pengurangan jumlah kunjungan pasien, tetapi tidak pada ruang gawat darurat dan ruang isolasi. Perawat yang bekerja di ruang tersebut memiliki risiko yang lebih besar untuk berinteraksi dengan pasien atau penderita yang dicurigai positif COVID-19. Hal tersebut dapat berpengaruh terhadap kesehatan mental mereka. Penelitian sebelumnya yang dilakukan sebelum pandemi menyebutkan bahwa permasalahan yang sering muncul selama bekerja yakni kekerasan dalam bentuk kalimat atau bahasa serta dan perilaku yang sering dilakukan oleh dokter dan atasan atau teman sejawat. Selain itu, perawat juga khawatir terkait kondisi pasien yang dirawatnya. Penelitian ini bertujuan untuk melaporkan dampak psikologi pada perawat yang memberikan perawatan pasien COVID-19 (Hu D, Kong Y, 2020).

Memberikan asuhan keperawatan pada pasien COVID-19 dapat berdampak negatif pada psikologis perawat. Dampak negatif psikologis yang dialami oleh perawat yakni kecemasan dan depresi. Kecemasan adalah status emosional negatif yang dipersepsikan secara individual dan merupakan salah satu gangguan psikologis yang sering dialami oleh perawat. Hasil penelitian sebelumnya menyebutkan bahwa penyebab kecemasan pada perawat yakni usia, status pernikahan, tingkat pendidikan, dan beban kerja (Hu D, Kong Y, 2020). 
Perawat yang masih muda dan belum menikah cenderung lebih mudah untuk mengalami kecemasan dan depresi dibandingkan dengan perawat yang lebih senior. Hal tersebut dapat terjadi karena perawat yang lebih senior memiliki lebih banyak pengalaman dalam melakukan perawatan kepada pasien dan memiliki dukungan dari anggota keluarga. Perawat dengan latar belakang pendidikan tinggi biasanya akan memiliki ekspektasi yang tinggi terhadap profesinya, tetapi akan lebih mudah merasa kecewa apabila hasil yang dicapainya tidak sesuai. Hal itu merupakan gejala dari kecemasan dan depresi. Pada masa pandemi seperti saat ini, jumlah pasien akan meningkat sehingga beban kerja akan meningkat, dan perawat akan merasa mudah lelah Psikologi negatif lain yang dialami oleh perawat yakni rasa takut, insomnia dan gangguan mental lain sehingga sangat berpengaruh kepada Penerapan Instrumen PPI SNARS (Kang L, 2020).

SNARS merupakan standart pelayanan berfokus pada pasien untuk meningkatkan mutu dan keselamatan pasien dengan pendekatan manajemen risiko di Rumah Sakit yang terdiri dari 16 bab untuk rumah sakitPendidikan dan 15 bab untuk rumah sakit nonpendidikan sehingga di masa pandemi covid-19 siperlukannya penerapan instrumen PPI SNARS terhadap kesejahteraan psikologis petugas penanggulangan COVID- 19. (KARS, 2017)

\subsubsection{Kesejahteraan Psikologis Petugas Penanggulangan Covid-19 sesudah diberikan Pengaruh Penerapan Instrumen PPI SNARS di RS Umum Gl. Tobing Tahun 2021}

Berdasarkan hasil penelitian menunjukkan bahwa Kesejahteraan Psikologis Petugas Penanggulangan Covid-19 sesudah diberikan treatment di RS Umum Gl. Tobing Tahun 2021 mayoritas sedang yaitu sebanyak 11 responden $(55,0 \%)$. Hal ini membuktikan bahwa penerapan instrument PPI SNARS sudah dapat mengurangi rasa kecemasan psikologis pada petugas Penanggulangan Covid-19.

Guna meningkatkan kesiapan RS dalam mengendalikan COVID-19, PERSI bekerja sama dengan Organisasi Kesehatan Dunia (WHO) melaksanakan webinar yang diikuti seluruh direktur atau kepala RS seluruh Indonesia pada Rabu (18/3) kemarin. Pada kesempatan ini PERSI pun mengimbau seluruh RS untuk melakukan Pencegahan dan Pengendalian Infeksi (PPI) secara tepat. PPI bertujuan menurunkan atau meminimalkan insiden rate infeksi terkait dengan pelayanan kesehatan pada pasien, petugas, dan pengunjung serta masyarakat sekitar rumah sakit dan fasilitas pelayanan kesehatan lainnya, dengan mempertimbangkan cost effectiveness.

Berbagai unsur yang harus diperhatikan oleh PPI adalah pentingnya Alat Pelindung Diri (APD) yang harus digunakan/dipakai jika melakukan tindakan untuk menghindarkan terpapar atau kemungkinan terpapar darah, cairan tubuh, sekresi, ekskresi, kecuali keringat. APD harus segera dilepas jika selesai tindakan. APD sendiri terdiri atas pelindung kaki/sepatu, gaun, masker, pelindung mata/wajah, pelindung rambut kepala dan masker.

Tujuan pengorganisasian bagian PPI merupakan mengidentifikasi dan menurunkan risiko infeksi silang antara pasien, staf, pegawai profesional kesehatan, kontrak, sukarela, 
mahasiswa dan pengunjung. Risiko infeksi \& aktivitas bagian bisa tidak sinkron menurut satu instansi rumah sakit ke instansi yang lainnya bergantung dalam aktivitas klinis dan pelayanan instansi rumah sakit, populasi pasien yang dilayani, lokasi geografi, jumlah pasien, dan jumlah pegawai. Program PPI akan efektif bila memiliki pimpinan yang ditetapkan, training dan pendidikan staf yang baik, metode buat mengidentifikasi dan agresif dalam wilayah berisiko infeksi, kebijakan dan mekanisme yang memadai, juga melakukan koordinasi ke semua ruangan rumah sakit.

Dalam melaksanakan kegiatan PPI diperlukan energi supaya target bisa tercapai. Dalam bekerja perawat PPI bisa dibantu beberapa perawat penghubung berdasarkan tiap unit, terutama yang berisiko terjadi infeksi. Perawat penghubung PPI/IPCLN menjadi perawat pelaksana harian bertugas: a. Mencatat data surveilans berdasarkan setiap pasien pada unit rawat inap masing- masing. b. Memberikan motivasi dan mengingatkan aplikasi kepatuhan PPI dalam setiap personil ruangan pada unitnya masing-masing. c. Memonitor kepatuhan petugas kesehatan yang lain pada penerapan kewaspadaan isolasi. d. Jika masih ada infeksi potensial KLB melakukan penyuluhan bagi pengunjung \& konsultasi mekanisme PPI, dan berkoordinasi menggunakan IPCN. e. Memantau aplikasi penyuluhan bagi pasien, famili dan pengunjung, dan konsultasi mekanisme yang wajib dilaksanakan. (KARS, 2020)

Manajemen rumah sakit menyediakan sumber daya untuk mendukung pelaksanaan program PPI, disinfektan (misalnya sabun antiseptik) dan anggaran pelatihan PPI (dasar maupun lanjutan) yang dilaksanakan internal maupun di luar rumah sakit. Selain itu, anggaran juga diperlukan untuk pemeriksaan kultur, pengadaan alat pelindung diri dan kebutuhan lainnya. Rumah sakit menjamin tersedia anggaran yang cukup untuk melaksanakan program PPI dengan efektif.

\subsubsection{Pengaruh Penerapan Instrumen PPI SNARS Terhadap Kesejahteraan Psikologis Petugas Penanggulangan Covid-19 Di RS Umum Gl. Tobing Tahun 2021}

Berdasarkan analisis data menunjukan Kesejahteraan Psikologis Petugas Penanggulangan Covid-19 di RS Umum Gl. Tobing Tahun 2021 sebelum dan sesudah diberikan perlakuan sebanyak 10 orang petugas masuk dalam kategori berat dan sesudah penerapan instrument PPI SNARS menurun menjadi 3 orang petugas yang mengalami psikologi berat, yang ringan menjadi 6 petugas dan yang sedang menjadi 11 petugas.

Berdasarkan Hasil uji statistic dengan menggunakan Uji Wilcoxon diketahui bahwa nilai p $(0,001)<\alpha(0,05)$ artinya Ho ditolak, jadi terdapat pengaruh Penerapan Instrumen PPI SNARS (Standar Nasional Akreditasi Rumah Sakit) Terhadap Kesejahteraan Psikologis Petugas Penanggulangan Covid-19 Di RS Umum Gl. Tobing Tahun 2021. Hasil ini membuktikan bahwa Penerapan Instrumen PPI SNARS (Standar Nasional Akreditasi Rumah Sakit) dapat memberikan pengaruh baik terhadap Kesejahteraan Psikologis Petugas Penanggulangan Covid-19 di RS Umum Gl. Tobing Tahun 2021.

Beberapa PPI yang perlu dilakukan RS, pun dijelaskan dalam kesempatan ini, seperti PPI dalam melaksanakan triase, PPI dalam ruang konsultasi untuk pasien dengan keluhan 
pernapasan, PPI dalam ruangan isolasi untuk pasien dalam pengawasan, dan PPI dalam ruang isolasi untuk kasus terkonfirmasi. Sementara, terkait alat kesehatan (alkes), semuanya harus melalui proses pre-cleaning - cleaning - disinfeksi. Sterilisasi dilakukan sesuai klasifikasi peralatan; kritikal- semi serta ritikal-non kritikal. Selanjutnya, simpan peralatan yang sudah diproses sesuai kebijakan dan SOP, tidak menempatkan peralatan kesehatan sembarang tempat, serta tidak menggunakan peralatan kesehatan sebelum diproses setelah dipakai sebelumnya.

Untuk perawatan linen, bisa dilakukan dengan mengganti linen setiap satu atau dua hari atau jika kotor, dan sesuai dengan kebijakan RS. Linen kotor pun perlu dipisahkan antara linen ternoda darah dan cairan tubuh dengan linen kotor tanpa noda darah dan cairan tubuh. Setelah itu, tempatkan linen bersih pada lemari tertutup, dan tidak bercampur dengan peralatan lainnya. (Costy, 2020)

Terkait lingkungan, Costy (2020) mengungkapkan pentingnya memperhatikan ventilasi udara ruangan yang bersih, baik, dan tidak bau, serta pertahankan mutu air bersih, juga permukaan lingkungan ruangan yang senantiasa dalam kondisi bersih. Berikutnya, tempatkan peralatan ruangan sedemikian rupa yang bisa dapat dengan mudah dibersihkan. Dalam PPI ini RS perlu melakukan memasang poster tentang informasi kebersihan tangan dan kebersihan pernapasan, meminta sesama pasien untuk saling menjaga jarak minimal 1 meter, petugas kesehatan mempertahankan jarak 1 meter, tanpa Alat Pelindung Diri (APD), pengenalan dini gejala dan rujukan langsung pasien dengan gejala pernafasan ke ruang konsultasi yang ditunjuk

Pasca tangani pasien dengan gangguan pernafasan, petugas medis perlu melakukan Bersihkan ruangan dengan air dan sabun serta deterjen yang umumnya digunakan RS, Petugas kebersihan wajib memakai APD seperti, gaun, masker medis, sarung tangan heavy duty, kacamata pelindung dan sepatu boot, Mendesinfeksi alat-alat medis yang telah digunakan. (WHO merekomendasikan untuk menggunakan $70 \%$ ethyl alcohol dalam mendesinfeksi area atau tempat dengan permukaan kecil yang digunakan, ataupun alat untuk tindakan pada pasien. Serta penggunaan 0,5\% sodium hypochlorite yang setara $5000 \mathrm{ppm}$ untuk desinfeksi permukaan) dan Manajemen sampah dalam ruangan sesuai standar medis tiap rumah sakit.

\section{Kesimpulan}

Berdasarkan uraian dari hasil penelitian dan pembahasan, maka dapat disimpulkan sebagai berikut:

1. Kesejahteraan Psikologis Petugas Penanggulangan Covid-19 sebelum diberikan penerapan instrumen PPI SNARS (Standar Nasional Akreditasi Rumah Sakit) Di RS Umum Gl. Tobing Tahun 2021 mayoritas mengalami kecemasan psikologis berat yaitu sebanyak 10 responden $(50,0 \%)$

2. Kesejahteraan Psikologis Petugas Penanggulangan Covid-19 sesudah diberikan penerapan instrumen PPI SNARS (Standar Nasional Akreditasi Rumah Sakit) Di RS Umum Gl. Tobing Tahun 2021 mayoritas kecemasan psikologis sedang yaitu sebanyak 11 responden $(55,0 \%)$ 
3. Ada pengaruh Penerapan Instrumen PPI SNARS (Standar Nasional Akreditasi Rumah Sakit) Terhadap Kesejahteraan Psikologis Petugas Penanggulangan Covid19 Di RS Umum Gl. Tobing Tahun 2021. Hasil ini membuktikan bahwa Penerapan Instrumen PPI SNARS (Standar Nasional Akreditasi Rumah Sakit) dapat memberikan pengaruh yang baik terhadap Kesejahteraan Psikologis Petugas Penanggulangan Covid-19 Di RS Umum Gl. Tobing Tahun 2021.

\section{Referensi}

Cai H. Sex difference and smoking predisposition in patients with COVID-19. Lancet Respir Med. 2020; published online March 11. DOI: 10.1016/S22132600(20)30117-X

Chan JF-W, Kok K-H, Zhu Z, Chu H, To KK-W, Yuan S, et al. Genomic characterization of the 2019 novel human-pathogenic coronavirus isolated from a patient with atypical pneumonia after visiting Wuhan. Emerg Microbes Infect. 2020;9(1):221-36

Chen H, Guo J, Wang C, Luo F, Yu X, Zhang W, et al. Clinical characteristics and intrauterine vertical transmission potential of COVID-19 infection in nine pregnant women: a retrospective review of medical records. Lancet. 2020;395(10226):809-15.

Dewi Purnamasari, 2018, Kesiapan Akreditasi Program Khusus (4 Pelayanan) Versi Standar Nasional Akreditasi Rumah Sakit (SNARS) di RSIA Abdhi Famili Kabupaten Banyuwang.

De Wit E, van Doremalen N, Falzarano D, Munster VJ. SARS and MERS: recent insights into emerging coronaviruses. Nat Rev Microbiol. 2016;14(8):523- 34.

Direktorat Jenderal Pencegahan dan Pengendalian Penyakit. Pedoman Kesiapsiagaan Menghadapi Coronavirus Disease (COVID-19) Maret 2020. Jakarta: Kementerian Kesehatan Republik Indonesia; 2020.

Hu D, Kong Y, Li W, Han Q, Zhang X, Zhu LX, et al. Frontline Nurses' Burnout, Anxiety, Depression, and Fear Statuses and Their Associated Factors During the COVID-19 Outbreak in Wuhan, China: A Big-Scale Cross- Sectional Study. SSRN Electron J. 2020;000. 14.

Kang L, Ma S, Chen M, Yang J, Wang Y, Li R, et al. Impact on mental health and perceptions of psychological care among medical and nursing staff in Wuhan during the 2019 novel coronavirus disease outbreak: A cross- sectional study. Brain Behav Immun. 2020;(March):1-7

Kementerian Kesehatan Republik Indonesia. Info Infeksi Emerging Kementerian Kesehatan RI [Internet]. 2020 [updated 2020 March 30; cited 2020 March 31]. Available from: https:// infeksiemerging.kemkes.go.id/.

Qin C, Liu F, Yen TC, Lan X. 18F-FDG PET/CT findings of COVID-19: a series of four highly suspected cases. Eur J Nucl Med Mol Imaging. 2020; published online February 22. DOI: 10.1007/ s00259-020-04734-w.

Riedel S, Morse S, Mietzner T, Miller S. Jawetz, Melnick, \& Adelberg's Medical Microbiology. 28th ed. New York: McGraw- Hill Education/Medical; 2019. p.617-22.

Rothan HA, Byrareddy SN. The epidemiology and pathogenesis of coronavirus disease (COVID-19) outbreak. J Autoimmun. 2020; published online March 3. DOI: 10.1016/j.jaut.2020.102433

WHO. On the front line of COVID-19: inspiring stories of health care workers $1 / 13$. :1- 
13.

Wang J, Zhou M, Liu F. Exploring the reasons for healthcare workers infected with novel coronavirus disease 2019 (COVID-19) in China. Hosp Infect. 2020; published online March 5. DOI: 10.1016/j.jhin.2020.03.002.

Wang X, Pan Z, Cheng Z. Association between 2019-nCoV transmission and N95 respirator use. J Hosp Infect. 2020; published online March 3. DOI: 10.1016/j.jhin.2020.02.021.

World Health Organization. Situation Report - 10 [Internet]. 2020 [updated 2020 January 30; cited 2020 March 15]. Available from: https://www.who.int/docs/default-source/ coronaviruse/situationreports/20200130-sitrep-10-ncov. pdf?sfvrsn=d0b2e480_2

World Health Organization. Situation Report - 42 [Internet]. 2020 [updated 2020 March 02; cited 2020 March 15]. Available from: https://www.who.int/docs/default-source/ coronaviruse/situation eports/ 20200302-sitrep-42-covid-19. pdf?sfvrsn=224c1add_2. Wu YC, Chen CS, Chan YJ. The outbreak of COVID-19 -An overview. J Chin Med Assoc. 2020;217-20.

Yuen KS, Ye ZW, Fung SY, Chan CP, Jin DY. SARS-CoV-2 and COVID-19:The most important research questions. Cell Biosci [ $\mathrm{Int}$ e r n e t] . $2020 ; 10$ ( 1 ) : 1 5. A v a i 1 a b l e f r o m : https://doi.org/10.1186/s13578-020- 00404-4

Zhou P, Yang X-L, Wang X-G, Hu B, Zhang L, Zhang W, et al. A pneumonia outbreak associated with a new coronavirus of probable bat origin. Nature. 2020;579(7798):270-3.

Zhang H, Penninger JM, Li Y, Zhong N, Slutsky AS. Angiotensin- converting enzyme 2 (ACE2) as a SARS-CoV-2 receptor: molecular mechanisms and potential therapeutic target. Intensive Care Med. 2020; published online March 3. DOI: $10.1007 / \mathrm{s} 00134-020-05985-9$ 